\title{
TEST OF A MODEL PREDICTING EQUILIBRIUM FREQUENCIES OF FEMALES IN POPULATIONS OF GYNODIOECIOUS ANGIOSPERMS
}

\author{
C. J. WEBB \\ Botany Division, DSIR, Private Bag, Christchurch, New Zealand \\ Received $15 . x .80$
}

\section{SUMMARY}

Flowering and fruiting of males and females were compared in field populations of 13 species of New Zealand apioid Umbelliferae, which were selected to include a range of breeding systems from strict dioecy to various states of gynodioecy. In all populations, sex ratios were male-biased and, on average, males had more inflorescences per plant and more flowers per inflorescence than did females. However, females invariably had a higher proportion of ovarybearing flowers. There was no significant difference between males and females in the proportion of ovary-bearing flowers which set fruit, or in the proportion of fruits which set both mericarps. Weight, length and germination of mericarps from males and females were also similar. In one species the progeny of females was larger in diameter than progeny of males before first flowering.

The data are compared with the equilibrium values predicted by a genic model for the maintenance of females in gynodioecious populations. Results are in general agreement with the model, and deviations from the theoretical curve are discussed in relation to the reproductive biology of the species.

\section{INTRODUCTION}

THE frequency of female plants in populations of gynodioecious species is determined by a number of factors including the relative seed fecundity of males and females, the system by which sex is determined, and differential survival of the sexes. Models predicting equilibrium frequencies of female plants have been formulated for when sex is determined cytoplasmically or by simple one or two gene systems (Lewis, 1941; Lloyd, 1974a, b, 1976; Charlesworth and Charlesworth, 1978), by systems involving overdominance (Ross and Wier, 1975), or by combined genic and cytoplasmic systems (Charlesworth and Ganders, 1979). There have been only a few studies which attempt to fit data to these models, e.g., Lloyd, 1976; Horovitz and Beiles, 1980; Krohne et al., 1980; Philipp, 1980.

Five genera of New Zealand apioid Umbelliferae display a range of forms of sexual dimorphism from strict dioecy in Anisotome and Aciphylla, to various states of gynodioecy and rarely andromonoecy in Gingidia, Scandia and Lignocarpa (Webb, 1979a). The polliniferous plants of these gynodioecious species may set abundant, little, or no fruit and are regarded here as inconstant or constant males in the sense of Lloyd (1974a).

Data gathered for representative species among these 5 genera are presented here, and related to a simple genic model of the equilibrium between males and females in gynodioecious populations, by comparing actual values for sex ratios in field populations, and ovule contributions of males and females, with the predicted values. 


\section{EQUAL FITNESS GENIC MODEL}

If male sterility in gynodioecious species is inherited by any mode of genic system for which all sex-determining genotypes of the same sex have equal average fitness, and if males and females survive at the same rate, then at equilibrium

$$
C=\frac{1-2 p}{2(1-p)} \quad \text { (Lloyd, 1976) }
$$

where $C=$ relative $\delta / q$ ovule contribution, i.e., the relative number of genomes contributed via ovules by individual males and females to the next generation at sexual maturity as estimated from the relative quantity and quality of fruit produced by males and females, and where $p=$ proportion of females $(0<p<1)$.

Three independent groups of factors affect $C$ : firstly, relative male/female seed fecundity including effects due to ovule number and maternal aid as well as the rate of self-fertilisation and inbreeding effects; second, the relative rates of fertilisation of fertilisable ovules on males and females due to pollination conditions, and third, the relative fitness component of seeds borne on the two sexes due to the sex genotypes of the seeds (Lloyd, 1976).

Initial investigation of Gingidia montana has indicated that inheritance of male sterility in these Umbelliferae is probably genic rather than cytoplasmic (Webb, 1979a). As the exact form of inheritance has not been worked out it is possible that the system is one of cytoplasmic male-sterility with a restorer gene, although Charlesworth and Ganders (1979) suggest that this form of control of gynodioecy should be rare in natural populations.

Evidence that males survive longer than females in the dioecious genera Anisotome and Aciphylla has been presented elsewhere (Lloyd and Webb, 1977; Webb and Lloyd, 1980). Differential survival is less likely in gynodioecious species because of the reduced distinction between the energy demands made on males and females by sexual reproduction, as males of gynodioecious species produce fruit in addition to pollen. There is some evidence that differential survival is unimportant in gynodioecious taxa (Webb and Lloyd, 1980).

\section{Methods AND RESUlts}

Eighteen populations of 10 gynodioecious and 3 dioecious species were investigated so that values for $p$ and $C$ could be calculated. The dioecious species in Anisotome and Aciphylla are included for comparison. Of the factors which go to make up $C$, the number of flowers per plant and the proportion of ovary-bearing flowers were recorded for all populations, with the exception of Scandia geniculata which has numerous inflorescences. The proportion of ovary-bearing flowers setting fruit, the number of mericarps per fruit, fruit quality and germination, and the growth of seedlings were investigated in representative species.

\section{(i) Proportion of females, $\mathrm{p}$}

Sex ratios were recorded at anthesis and the proportion of female plants calculated (table 1). Counts were usually based on more than 100 plants, 
TABLE 1

Proportion of female plants and relative potential fruit set of males and females in populations of Gingidia, Scandia, Lignocarpa, Anisotome and Aciphylla

\begin{tabular}{|c|c|c|c|c|c|c|c|}
\hline \multirow[b]{2}{*}{ Species } & \multirow{2}{*}{$\begin{array}{c}\text { Proportion } \\
\text { of female } \\
\text { plants }\end{array}$} & \multicolumn{3}{|c|}{$\begin{array}{c}\text { Average No. of } \\
\text { flowers/plant }\end{array}$} & \multicolumn{2}{|c|}{$\begin{array}{c}\text { Average } \\
\text { proportion of } \\
\text { ovary-bearing } \\
\text { flowers }\end{array}$} & \multirow{2}{*}{$\begin{array}{c}\text { Relative } \\
\text { potential } \\
\text { fruit set } \\
\delta / \%\end{array}$} \\
\hline & & 8 & $q$ & $\delta / q$ & $\delta$ & 우 & \\
\hline G. montana & $0.35^{* *}$ & 1413 & 702 & $2 \cdot 01^{* *}$ & 0.35 & $1 \cdot 00$ & 0.70 \\
\hline G. montana & $0 \cdot 30^{* *}$ & 541 & 536 & $1 \cdot 01$ & $0 \cdot 16$ & $1 \cdot 00$ & $0 \cdot 16$ \\
\hline G. decipiens & $0 \cdot 12^{* *}$ & 191 & 36 & $5 \cdot 31 * *$ & 0.13 & $1 \cdot 00$ & 0.70 \\
\hline G. decipiens & $0 \cdot 25^{* *}$ & 89 & 32 & $2 \cdot 78^{* *}$ & 0.11 & $1 \cdot 00$ & 0.31 \\
\hline G. trifoliolata & $0 \cdot 14^{* *}$ & 80 & 66 & $1 \cdot 21^{*}$ & 0.57 & $1 \cdot 00$ & 0.69 \\
\hline G. baxteri & $0 \cdot 31^{* *}$ & 14 & 13 & $1 \cdot 08$ & 0.59 & $1 \cdot 00$ & 0.64 \\
\hline G. baxteri & $0 \cdot 16^{* *}$ & 23 & 17 & $1 \cdot 35$ & 0.26 & $0.75 \dagger$ & 0.47 \\
\hline G. enysii & $0.04^{* *}$ & 173 & 92 & $1 \cdot 88^{* *}$ & 0.22 & $1 \cdot 00$ & 0.42 \\
\hline G. flabellata & $0.003^{* *}$ & 61 & 26 & $2 \cdot 35^{* *}$ & 0.45 & $1 \cdot 00$ & $1 \cdot 05$ \\
\hline G. flabellata & $0 \cdot 21 * *$ & 17 & 9 & $1 \cdot 89^{* *}$ & 0.42 & 1.00 & 0.79 \\
\hline S. rosaefolia & $0 \cdot 28^{* *}$ & 559 & 221 & $2 \cdot 53^{* *}$ & $0 \cdot 22$ & $1 \cdot 00$ & 0.56 \\
\hline S. rosaefolia & 0.46 & 1055 & 809 & $1 \cdot 30^{* *}$ & 0.02 & $1 \cdot 00$ & 0.03 \\
\hline S. geniculata & $0.07^{* *}$ & 26 & 13 & $2 \cdot 00 \ddagger^{* *}$ & 0.27 & $1 \cdot 00$ & - \\
\hline L. carnosula & 0.41 & 168 & 132 & $1 \cdot 27^{*}$ & 0.44 & $1 \cdot 00$ & 0.56 \\
\hline L. diversifolia & $0 \cdot 36^{*}$ & 141 & 78 & $1 \cdot 81^{* *}$ & 0.02 & $1 \cdot 00$ & 0.04 \\
\hline An. filifolia & $0 \cdot 20^{* *}$ & 440 & 87 & $5 \cdot 06^{* *}$ & 0 & $1 \cdot 00$ & 0 \\
\hline An. flexuosa & $0.39^{*}$ & 270 & 84 & $3 \cdot 21^{* *}$ & 0 & $1 \cdot 00$ & 0 \\
\hline Ac. monroi & $0 \cdot 25^{* * *}$ & 288 & 66 & $4 \cdot 36^{* *}$ & 0 & $1 \cdot 00$ & 0 \\
\hline
\end{tabular}

† Some female plants have a proportion of neuter flowers in this population.

$\ddagger$ Result for flowers/inflorescence only.

$*(P<0 \cdot 05),{ }^{* *}(P<0 \cdot 01)$; calculated on hypothesis of equality.

and in a few species with smaller populations, all plants were sexed. There is no difficulty distinguishing the two sexes at or near anthesis, and there were rarely difficulties in determining individual plant limits. As, in the gynodioecious species, nearly all mature plants flower, differing flowering propensity of the sexes is unlikely to affect sex ratio counts.

The frequency of female plants varied from a near andromonoecious population of Gingidia flabellata through to a population of Scandia rosaefolia with 46 per cent female plants (table 1 ). In no population did females exceed 50 per cent. Further sex ratios are reported for these species and other species of these genera by Webb and Lloyd (1980).

\section{(ii) Flowers per plant}

The average number of flowers per plant for males and females was calculated from the number of inflorescences per plant, and the number of flowers per inflorescence (table 1). Flower numbers were mostly recorded from samples of one inflorescence per plant for smaller species, and from samples of umbellets for species with very large inflorescences. Where possible, more than 20 plants of each sex were sampled for each population. Males usually have more inflorescences per plant, almost always more flowers per inflorescence, and as a result, more flowers per plant than female plants. 


\section{(iii) Proportion of ovary-bearing flowers}

One inflorescence per plant was sampled from 30 to 40 male plants and about 20 female plants in each population, and the proportion of ovarybearing flowers recorded. Male and hermaphrodite (perfect) flowers of male plants are readily distinguished at anthesis (Webb, 1979a). There is considerable variation within and between populations in the proportion of ovary-bearing flowers in male plants (Webb, 1979a), but female plants almost invariably have only female flowers (table 1 ). The average proportion of ovary-bearing flowers in male plants of a population varied from 0 in dioecious species to 0.59 in one population of Gingidia baxteri (table 1). From the average number of flowers per plant, and the proportion of ovary-bearing flowers, the relative potential fruit set of each population can be calculated (table 1). Potential fruit set of males is almost always less than that of females.

\section{(iv) Proportion of ovary-bearing flowers setting fruit}

In five species, samples from several plants of each sex were collected when fruit was fully mature but intact. The proportion of ovary-bearing flowers with at least one fully-formed mericarp was noted. In all species examined a very high proportion of ovary-bearing flowers set fruit in both sexes and the sexes do not differ significantly (table 2). Other species of this

\section{TABLE 2}

Proportion of ovary-bearing flowers setting fruit in male and female plants in populations of Gingidia, Scandia, Lignocarpa and Anisotome $(\mathrm{n}=$ sample size, $\overline{\mathrm{x}}=$ mean $)$

\begin{tabular}{|c|c|c|c|c|c|}
\hline \multirow[b]{3}{*}{ Species } & \multirow[b]{3}{*}{ Sample nature } & \multicolumn{4}{|c|}{$\begin{array}{c}\text { Average proportion of ovary-bearing } \\
\text { fowers setting fruit }\end{array}$} \\
\hline & & \multicolumn{2}{|c|}{ g } & \multicolumn{2}{|c|}{$q$} \\
\hline & & $n$ & $\vec{x}$ & $n$ & $\bar{x}$ \\
\hline G. montana & whole plant & 11 & 0.95 & 7 & $0.98 \dagger$ \\
\hline G. decipiens & whole plant & 23 & $0 \cdot 81$ & 24 & 0.89 \\
\hline G. decipiens & whole plant & 20 & 0.94 & 20 & 0.93 \\
\hline S. geniculata & several inflor. & 5 & 0.98 & 3 & 0.97 \\
\hline L. diversifolia & one inflor. & 4 & 1.00 & 3 & $1 \cdot 00$ \\
\hline A. folifolia $\$$ & whole plant & - & - & 24 & 0.90 \\
\hline
\end{tabular}

$\ddagger$ Dioecious species-males have no ovary-bearing flowers.

$\dagger$ Differences for all species non-significant by $t$-test.

group of Umbelliferae were examined in the field, but not scored in detail, and were found to have similarly high levels of fruit set. These fruit set values are very high when compared with some other Umbelliferae and many species of other families (Lloyd et al., 1980).

\section{(v) Number of mericarps per fruit}

In Umbelliferae there may be one or two properly-formed mericarps per schizocarp. Three species were examined. Males and females of Gingidia montana and $G$. decipiens, and females of the dioecious Anisotome filifolia had over 99 per cent of fruits with two fully-formed mericarps. 


\section{(vi) Quality and germination of mericarps}

In three species, mericarp length was measured for a random sample of 200 mericarps for each sex, and for four populations, samples of mericarps from male and from female plants were weighed (table 3). Mericarps

\section{TABLE 3}

Length $(\mathrm{mm})$ and weight $\left(\mathrm{g} \times 10^{-3}\right)$ of mericarps gathered from male and female plants in populations of Gingidia and Scandia

\begin{tabular}{|c|c|c|c|c|}
\hline \multirow[b]{2}{*}{ Species } & \multicolumn{2}{|c|}{ Mean mericarp length } & \multicolumn{2}{|c|}{ Mean mericarp weigh } \\
\hline & from $\delta^{\star}$ & from $q$ & from $\delta$ & from $q$ \\
\hline G. montana & - & - & $1 \cdot 77$ & $1.55 \dagger$ \\
\hline G. montana & $4 \cdot 48$ & $4 \cdot 44 \dagger$ & $1 \cdot 60$ & $1 \cdot 66$ \\
\hline G. decipiens & $3 \cdot 70$ & $3 \cdot 83$ & $1 \cdot 50$ & $1 \cdot 37$ \\
\hline S. geniculata & $4 \cdot 89$ & $4 \cdot 87$ & $1 \cdot 60$ & $1 \cdot 61$ \\
\hline
\end{tabular}

gathered from male and female plants of Gingidia montana and Scandia geniculata were cold treated at $5^{\circ} \mathrm{C}$ in dark for 6 weeks, and then placed on moist germination pads at $25^{\circ} \mathrm{C}$ under light. Numbers of mericarps germinating were recorded weekly and no further germination occurred after 23 weeks in $G$. montana and 20 weeks in $S$. geniculata (table 4). Additional germination trials under greenhouse conditions gave similar germination percentages to those recorded in table 4 .

\section{TABLE 4}

Germination $(\%)$ of mericarps gathered from male and female plants $(\mathrm{n}=$ sample size)

\begin{tabular}{lcccc} 
& \multicolumn{4}{c}{ Mericarp germination } \\
& $n$ & from $\sigma^{*}$ & from $\%$ & \\
& 150 & 45 & 150 & $49 \dagger$ \\
Gingidia montana & 150 & 60 & 150 & $52 \dagger$ \\
Scandia geniculata & & & &
\end{tabular}

There was no significant difference between the rate of germination of mericarps gathered from male and female parent plants, nor were there differences in mericarp weight or length. Mericarps produced by males and females are apparently of equal quality.

\section{(vii) Growth of seedlings}

Plants raised from mericarps gathered from male and female plants in one population of Gingidia montana were planted out in trial plots. After about one year of growth and before first flowering, the diameters of all plants were measured and leaf numbers counted. In the following flowering season the sex of each plant was noted. 
There was no significant difference between male and female progeny in plant diameter or leaf number. But a comparison of the progeny of female parent plants with those of male parents showed that seedlings grown from mericarps gathered from females were about 15 per cent larger in plant diameter $(t=4 \cdot 14, p<0 \cdot 001)$ although they did not differ in leaf number (table 5).

\section{TABLE 5}

Plant diameter $(\mathrm{cm})$ and leaf number of sexed seedlings grown from mericarps gathered from male and female parent plants of Gingidia montana ( $\mathrm{n}=$ sample size, $\overline{\mathrm{x}}=$ mean)

\begin{tabular}{|c|c|c|c|c|c|}
\hline & \multicolumn{4}{|c|}{ Parent } \\
\hline & & & & & \\
\hline & & $n$ & $\bar{x}$ & $n$ & $\bar{x}$ \\
\hline t progeny & $\{$ plant diam. & 73 & $19 \cdot 8$ & 46 & $22 \cdot 9$ \\
\hline q progeny & $\left\{\begin{array}{l}\text { plant diam. } \\
\text { leaf no. }\end{array}\right.$ & $\begin{array}{l}15 \\
15\end{array}$ & $\begin{array}{l}20 \cdot 9 \\
15 \cdot 3\end{array}$ & $\begin{array}{l}37 \\
37\end{array}$ & $\begin{array}{l}23 \cdot 0 \\
18 \cdot 0\end{array}$ \\
\hline
\end{tabular}

\section{Fit OF DATA TO MODEL}

The above results show that male and female plants differ only in the number of flowers per plant, the proportion of ovary-bearing flowers, and in growth rates of their progeny. If seedling growth, which has been measured for only one species, is initially ignored in the calculation of $C$, then the relative potential fruit set (table 1) can be used as an estimate of $C$. Values of $C$ and $p$ are plotted in fig. 1 along with the theoretical curve. A non-linear regression function was fitted by Maximum Likelihood estimation, assuming a function of the form $C=(1-2 p) / k(1-p)$ where $k$ is a scale parameter modifying the theoretical relation $(k=2)$, and also assuming that $C$ is normally distributed for a given level of $p$. The Maximum Likelihood estimate is $k=1 \cdot 28$, S.E. $0 \cdot 15$ (fig. 1).

As predicted under most conditions by genic models of the control of gynodioecy, the frequency of females does not exceed 0.5 in any population (fig. 1). Also, as predicted there is clearly an inverse relationship between $C$ and $p$.

However, there are two main ways in which the points depart from the values predicted by the model. Firstly, at higher values of the relative ovule contribution, $C$, the estimated population values of $p$ are mostly greater than those predicted by the model. This deviation might be explained as follows: individual hermaphrodite flowers of male plants are weakly protandrous, but insufficiently so as to preclude self-pollination. Male plants are selffertile (Webb, 1979a), and very probably some fruit set by male plants results from self-fertilisation. Differences in seedling growth rates are probably a result of inbreeding depression, although they may also reflect differences in mericarp quality not evident in relative mericarp size, weight, or germination. In the single population examined, the effect of taking into account the difference in the growth rate of seedlings from male and female parents is to shift the $C$ value back toward the theoretical curve to the extent 


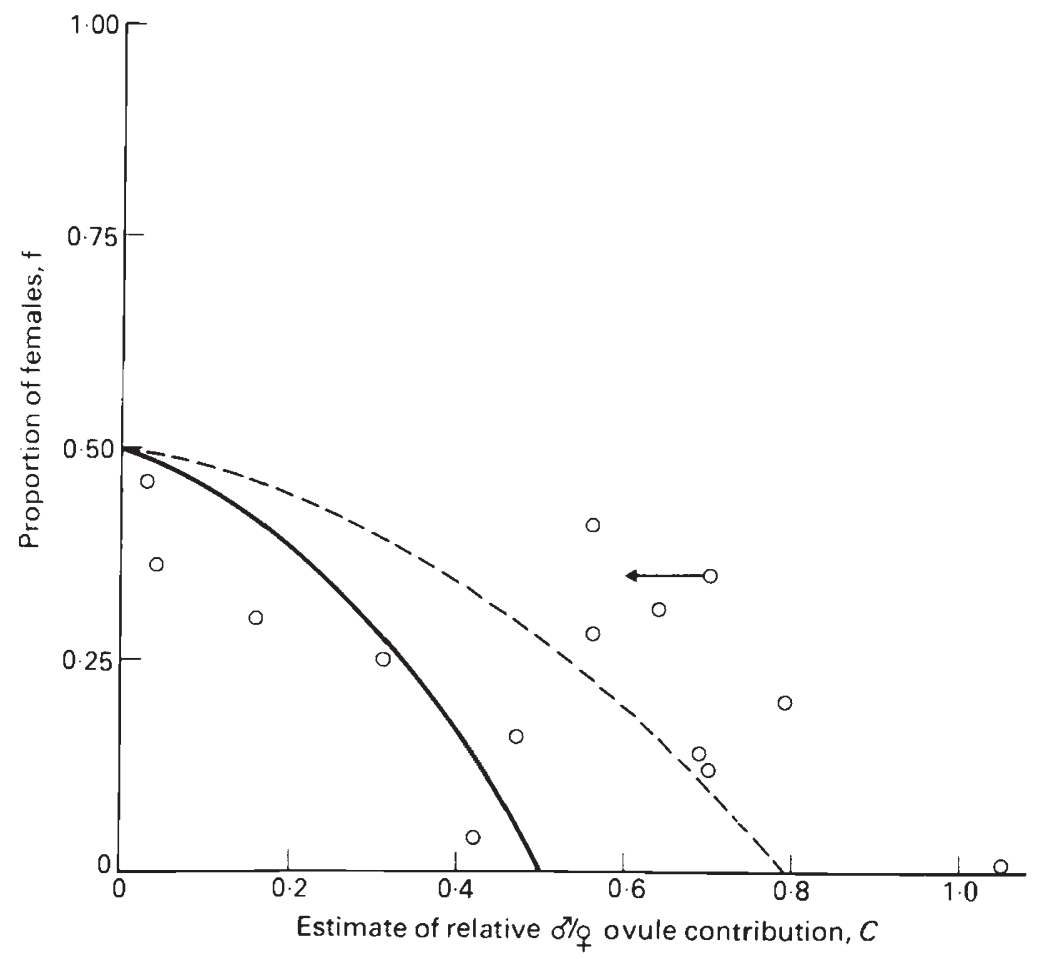

FIG. 1.-Relationship between the proportion of female plants, $p$, and estimate of relative $(\partial / q)$ ovule contribution, $C$, for populations of Gingidia, Scandia and Lignocarpa. The curves show equilibrium values for the model $C=(1-2 p) / 2(1-p)$ (solid line), and the fitted regression $C=(1-2 p) / 1 \cdot 28(1-p)$ (dashed line). The arrow indicates the extent to which measurement of relative seedling growth alters the estimate of $C$ for $G$. montana.

indicated by the arrow in fig. 1. It is possible that the effects of selffertilisation seen in inbreeding depression would be even more evident if progeny could be followed through a whole generation, and the population value of $C$ would then be much closer to the theoretical value. It would be anticipated that this phenomenon is not unusual and that other species with high values of $C$ would give similar results if this factor could be investigated.

Second, at low values of $C$ all the populations have values of $p$ which are lower than predicted by the model. Differential survival of the sexes may well account for this deviation. It was assumed in adopting this simplified model that the sexes survive at the same rate, but there is evidence from related dioecious species that males survive longer on average than do females (Lloyd and Webb, 1977; Webb and Lloyd, 1980). Populations with low $C$ values are those closest to dioecy, that is those with the greatest difference between male and female plants in ovule contributions, and these are therefore the populations most likely to show the effects of differential survival. If males outlive females, then the population sex ratios overestimate the equilibrium proportion of males. Similarly, if the values recorded for the strictly dioecious populations used for comparison were plotted they would lie on the axis $C=0$, with $p<0 \cdot 5$. 


\section{Discussion}

Although more detailed study of the extent to which inbreeding depression affects the growth of progeny is needed, the data presented here indicate that the frequency of female plants can be explained in terms of the relative ovule contributions of the two sexes. Differential survival of the sexes probably has an effect on the population sex ratio when males contribute relatively few ovules.

Lloyd (1976) considered gynodioecious species of 7 genera in diverse families, and showed that the frequency of female plants can generally be explained in terms of the model used here. Philipp (1980) has investigated the factors which maintain females at equilibrium in gynodioecious populations of Stellaria longipes, and other studies have provided data demonstrating the general reproductive superiority of females as ovule parents (e.g., Darwin, 1877; Burrows, 1960; Godley, 1963; Connor, 1974; Bawa, 1977; Webb, 1979b; Krohne et al., 1980). However, different factors which go to make up the relative ovule contribution are emphasised by different species.

The model evaluated here assumes no niche differentiation of the sexes as described by Freeman et al. (1980), and does not consider sexual selection (Willson, 1979). In future it may be possible to add such factors to models of the maintenance of gynodioecy.

Acknowledgments.-I am grateful to D. Charlesworth, H. E. Connor, E. J. Godley, and D. G. Lloyd for comments on a draft of the manuscript, A. Wallace for assistance with the regression analysis, and J. M. Cawley for drafting the figure. Part of this work was carried out while I held a Miss E. L. Hellaby Indigenous Grasslands Research Fellowship.

\section{REFERENCES}

BAWA, K. S. 1977. The reproductive biology of Cupania guatemalensis Radlk. (Sapindaceae). Evolution, 31, 52-63.

BURROws, C. J. 1960. Studies in Pimelea. I. The breeding system. Trans. Roy. Soc. New Zeal., $88,29-45$.

CHARLESWORTH, B., AND CHARLESWORTH, D. 1978. A model for the evolution of dioecy and gynodioecy. Amer. Nat., 112, 975-997.

CHARLESWORTH, D., AND GANDERS, F. R. 1979. The population genetics of gynodioecy with cytoplasmic-genic male-sterility. Heredity, 43, 213-218.

CONNOR, H. E. 1974. Breeding systems in Cortaderia (Gramineae). Evolution, 27, 663-678.

DARWIN, C. 1877. The Different Forms of Flowers on Plants of the same Species. Murray, London.

FREEMAN, D. C., HARPER, K. T., AND OSTLER, W. K. 1980. Ecology of plant dioecy in the intermountain region of western North America and California. Oecologia, 44, 410-417.

GODLEY, E. J. 1963. Breeding systems in New Zealand plants. 2. Genetics of the sex forms in Fuchsia procumbens. New Zeal. Jour. Bot., 1, 48-52.

HOROVITZ, A., AND BEILES, A. 1980. Gynodioecy as a possible population strategy for increasing reproductive output. Theor. App. Genet., 57, 11-15.

KROHNE, D. T., BAKER, I., AND BAKER, H. G. 1980. The maintenance of the gynodioecious breeding system in Plantago lanceolata L. Amer. Midl. Naturalist, 103, 269-279.

LEWIS, D. 1941. Male sterility in natural populations of hermaphrodite plants. New Phytol., 40, 56-63.

LLOYD, D. G. 1974a. Theoretical sex ratios of dioecious and gynodioecious angiosperms. Heredity, 32, 11-34.

LLOYD, D. G. 1974b. The genetic contribution of individual males and females in dioecious and gynodioecious angiosperms. Heredity, 32, 45-51. 
LLOYD, D. G. 1976. The transmission of genes via pollen and ovules in gynodioecious angiosperms. Theor. Pop. Biol., 9, 299-316.

LLOYD, D. G., AND WEBB, C. J. 1977. Secondary sex characters in plants. Bot. Rev., 43, 177-216.

LLOYD, D. G., WEBB, C. J., AND PRIMACK, R. B. 1980. Sexual strategies in plants II. Data on the temporal regulation of maternal investment. New Phytol., 86, 81-92.

PHILIPP, M. 1980. The reproductive biology of Stellaria longipes Goldie as revealed by a cultivation experiment. New Phytol., 85, 557-569.

ROSS, M. D., AND WEIR, B. S. 1975. Maintenance of male sterility in plant populations III. Mixed selfing and random mating. Heredity, 35, 21-29.

WEBB, C. J. $1979 a$. Breeding systems and the evolution of dioecy in New Zealand apioid Umbelliferae. Evolution, 33, 662-672.

WEBB, C.J. 1979 b. Breeding system and seed set in Euonymus europaeus (Celastraceae). $P$. Syst. Evol., 132, 299-303.

WEBB, C. J., AND LLOYD, D. G. 1980. Sex ratios in New Zealand apioid Umbelliferae. New Zeal. Jour. Bot., 18, 121-126.

WILlson, M. F. 1979. Sexual selection in plants. Amer. Nat., 113, 777-790. 